\title{
Grape Leaffolder, Desmia funeralis (Hübner) (Insecta: Lepidoptera: Pyraustidae) 1
}

\section{F. W. Mead and Susan E. Webb ${ }^{2}$ \\ Introduction}

The grape leaffolder is a common and widely distributed species that is a minor pest of grapes in the United States. In California severe outbreaks have occurred in restricted areas during some years. These outbreaks have been associated with failures of parasites to attain their normal levels. In Florida the grape leaffolder has done substantial damage to grape leaves in September and October when growers have discontinued their spray programs after harvest.

Excessive defoliation may deplete the food reserves in the vine sufficiently to reduce the size of the next crop.

The ability to control grape pests in Florida is becoming more meaningful with the rebirth of the grape industry. At one time, bunch grape plantings numbered several thousand acres in Florida, then nearly disappeared from the adverse effects of Pierce's disease. Development of several resistant bunch grape varieties by the former University of Florida Central Florida Research and Education Center at Leesburg spurred renewed interest. Currently, the combined commercial muscadine and bunch grape acreage in Florida is estimated to be 1000 acres. There are eight farm wineries operating across the state. Grapes are also sold as fresh fruit and juice.

\section{Identification}

Eggs are small (about 1/32 inch long), flat, iridescent, elliptical structures laid singly on the underside of a leaf, often in the angles between a vein and the leaf surface.

Larvae are 3/4 inch long when fully grown. They are glossy, translucent yellow-green on the sides and somewhat darker above, with scattered fine yellow hairs on each segment. The head and prothoracic shield are light brown, and there are light brown spots on the sides of the first two thoracic segments.

Larvae wiggle vigorously when disturbed and drop to the ground.

Pupae average a little over 1/2 inch long; they are light brown just after pupation, but soon turn dark.

1. This document is EENY-192 (originally published as DPI Entomology Circular 87), one of a series of Featured Creatures from the Entomology and Nematology Department, Florida Cooperative Extension Service, Institute of Food and Agricultural Sciences, University of Florida. Published: February 2001. This document is also available on Featured Creatures Website at http://creatures.ifas.ufl.edu. Please visit the EDIS Website at http://edis.ifas.ufl.edu.

2. F. W. Mead, Florida Department of Agriculture and Consumer Services, Division of Plant Industry and Susan E. Webb, Entomology and Nematology, University of Florida, Gainesville, Florida.

The Institute of Food and Agricultural Sciences (IFAS) is an Equal Employment Opportunity - Affirmative Action Employer authorized to provide research, educational information and other services only to individuals and institutions that function without regard to race, creed, color, religion, age, disability, sex, sexual orientation, marital status, national origin, political opinions or affiliations. For information on obtaining other extension publications, contact your county Cooperative Extension Service office. Florida Cooperative Extension Service / Institute of Food and Agricultural Sciences / University of Florida / Larry R. Arrington, Interim Dean 


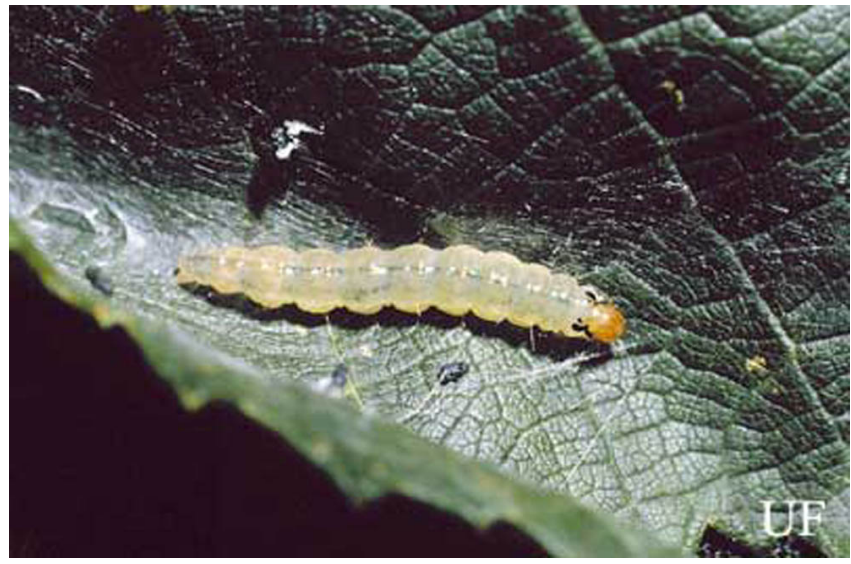

Figure 1. Larva of the grape leaffolder, Desmia funeralis (Hübner). Credits: F.L. Jensen, Farm Advisor, California

Adults have a wing expansion varying from about $4 / 5$ inch to nearly $11 / 4$ inches. The color of the wings is very dark brown, almost black, with a silvery or bluish iridescence. The forewings in both sexes have two nearly oval white spots. The hind wings of the male have one white bar which in the female is partly or completely divided into two spots. Both sexes have various amounts of white on the fringes of the wings and parts of the head, body, and legs. The antennae in the male appear thickened and notched near the middle, while in the female they are uniform and threadlike. Adults of other species of Desmia and certain other similar species in Florida have the white spots of the wings much more linear or are obviously different in number of spots or some other characteristic.

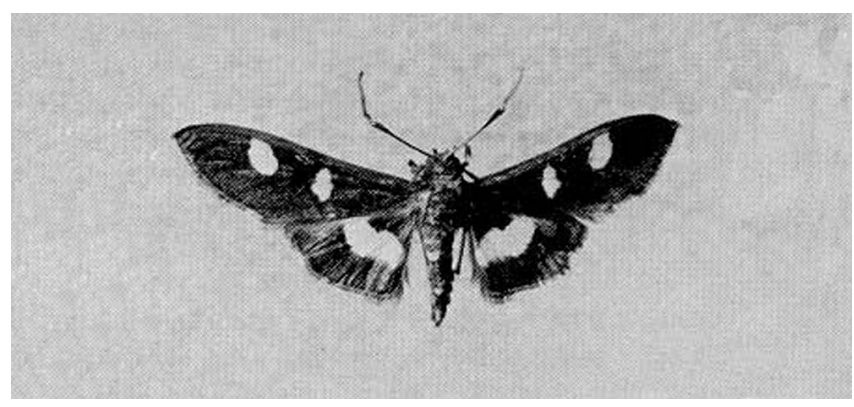

Figure 2. Adult grape leaffolder, Desmia funeralis (Hübner). Credits: Division of Plant Industry

In Florida adults have been collected regularly in Steiner and blacklight traps.

\section{Life History}

Winter is passed in the pupal stage in the folded and fallen leaves. The moths emerge in spring shortly after grape foliage appears and lay their eggs on the leaves. In Florida the earliest records for adults are in mid-February in the Sarasota area, but other February records include localities in Indian River, Manatee, Osceola, and Volusia counties. Adults have been taken all months of the year in Florida except January. Comparatively few larval records are available for Florida, but the earliest one is in May and the latest in December, with peak populations occurring from July into October. The numbers of first brood larvae are reported to be quite insignificant compared to the second brood. In the southern United States a third brood leads into the overwintering pupal stage.

Precise data on the developmental stages of Desmia funeralis in Florida are lacking, but Smith and Stafford (1955) give data for Fresno, California, that may approximate development in Florida. The moth flight period of the first brood occurred (at Fresno) from April 2 to May 24; egg hatching required 10 to 17 days. Total time in larval stages was three to four weeks, pupal time 10 to 14 days, total time from egg to emergence of moth $61 / 2$ to $71 / 2$ weeks. The second brood moth flight period was from June 15 to July 15; egg hatching required four to five days. Total time in larval stages was two to three weeks, pupal stage seven to 11 days, total time from egg to emergence of moth four to five weeks. The third brood moth flight period extended from August 3 to September 5; eggs hatched in four to five days, larvae required three to five weeks to complete growth, and ensuing pupae overwintered. Female moths of the second and third broods lay most of their eggs on leaves rolled by larvae of a previous brood. However, moths may fly into an uninfested vineyard as late as mid-summer and start what may become a serious leaffolder problem.

AliNiazee (1974) studied leaffolder development in the laboratory at $23.9 \pm 1{ }^{\circ} \mathrm{C}$. $\mathrm{He}$ found the average duration of larval stages to be as follows: first instar, 3.5 days; second instar, 3.9 days; third instar, 4.4 days; fourth instar, 4.3 days; fifth instar, 6.1 days.

Leaffolders feed on both muscadine and bunch grape leaves. Young larvae will tie together several muscadine leaves and feed in a group. Individual 
larvae begin making leaf rolls after one week (AliNiazee 1974). They may also use rolls made by an earlier generation. Larvae will fold, rather than roll, bunch grape leaves, which are thicker than muscadine leaves (McGiffen and Neunzig 1985).

Larvae make leaf rolls by spinning strands of silk which contract and pull the leaf together. Jensen (1966) noted that each bunch of strands contains 200 to 300 individual filaments and about 10 such ties are needed per roll, including some inside where they cannot be seen. Larvae feed on the free edge of the leaf inside the roll and make at least two such rolls during their development. They always remain inside the rolls or between leaves except when moving (at night) from one location to another. To form pupation sites, larvae make envelopes, often by cutting a small piece of leaf on three sides and folding it over (AliNiazee 1974). At the end of the season these will fall to the ground with the leaves to which they are attached.

AliNiazee (1974) monitored adult activity in the summer in California and found that moths were most active from midnight to the early morning hours.

\section{Detection and Damage}

Injury to the leaves is very characteristic and may be easily recognized. As soon as a larva is large enough it folds the leaf, exposing the under surface; the edge is held in place by bands of silk thread. It is within the protection of this fold that the larva feeds, skeletonizing the leaf of the upper surface. When the larvae are numerous the injury to the vine becomes conspicuous, even at a considerable distance, because the light color of the under surface of the folded leaves contrasts boldly with the dark green of the upper side normally presented, thus giving the vine a patchy appearance. Larvae roll muscadine leaves, which are thinner than bunch grape leaves.

\section{Hosts}

Wild and cultivated grapes, Vitis spp., are the principal hosts of the grape leaffolder. Two varieties of redbud, Cercis canadensis and C. chinensis; Virginia creeper, Parthenocissus quinquefolia; and Oenothera have been reported as occasional hosts.

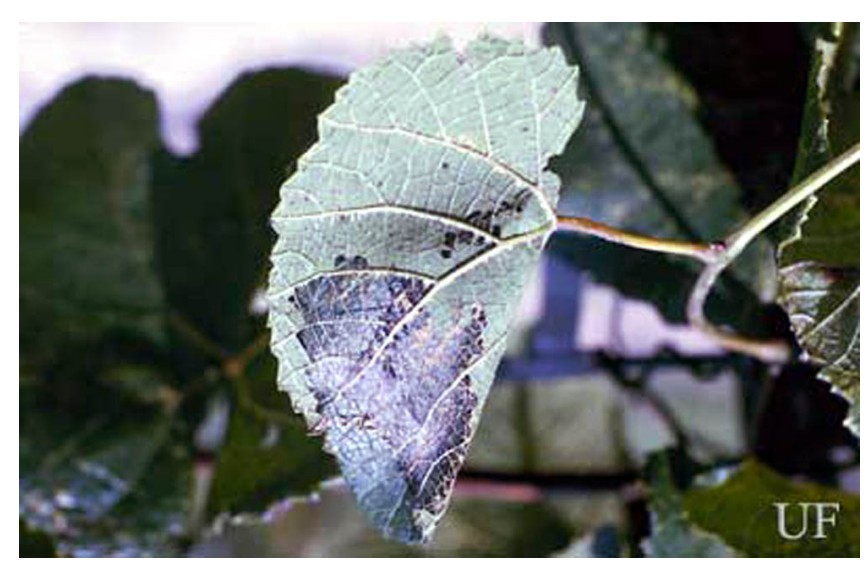

Figure 3. Damage to bunch grape foliage caused by the grape leaffolder, Desmia funeralis (Hübner). Credits: Warren Adlerz, University of Florida

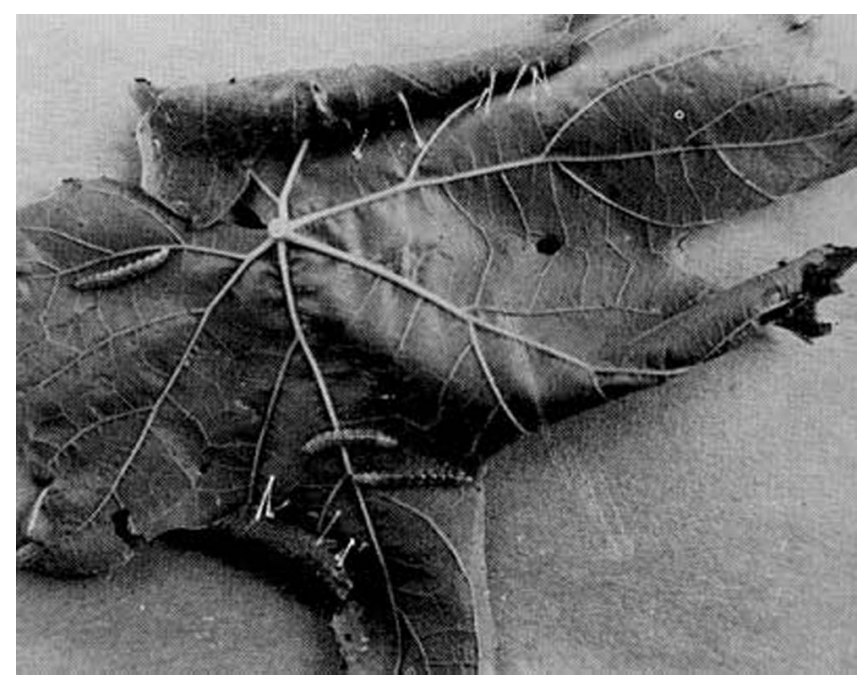

Figure 4. Damage to muscadine grape leaf with characteristic roll caused by the grape leaffolder, Desmia funeralis (Hübner), also showing silk strands. Larva removed from rolls for photographic purposes. Credits: F.L. Jensen, Farm Advisor, California

The varieties of grape more prone to attack are those having thinner, more tender, and hairy leaves.

\section{Parasitoids}

Many parasitoids have been reported from grape leaffolder. McGiffen and Neunzig (1985) reared larvae and found three species of tachinid flies as well as numerous hymenopterous parasitoids. In all, they found three species of braconid wasps, two species of ichneumonid wasps, and one eulophid wasp. 


\section{Management}

A standard insecticide employed against the "folder" is carbaryl (Sevin). Grapes must not be harvested within seven days of an application.

Double-check state recommendations before applying any insecticide. Tests in California and Florida using preparations of Bacillus thuringiensis (Bt) showed no significant differences in control between it and carbaryl, both providing good control. Home gardeners who do not want to use insecticides may get good results by thoroughly going over vines when folded or rolled leaves are in evidence and crushing the larvae by hand. Because the insect passes the winter in the pupal stage in fallen leaves, it is a good idea to rake up the leaves and destroy them.

For more information see the Insect Management Guide for Grapes (http://edis.ifas.ufl.edu/IG071).

\section{Selected References}

AliNiazee, M. T. 1974. Contribution to the bionomics of the grape leaffolder, Desmia funeralis (Hübner): A laboratory study with field observations. Pan-Pacific Entomol. 50: 269-278.

Jensen, F.L. 1966. Grape leaffolder control with Bacillus thuringiensis. Calif. Agr. 20: 2-3.

Kimball, C.P. 1965. The Lepidoptera of Florida; an annotated checklist. Arthropods of Florida and neighboring land areas Vol. 1. FL Dep. Agric., Div. Plant Industry. 363 p.

McGiffen, K. C. and H. H. Neunzig. 1985. A guide to the identification and biology of insects feeding on muscadine and bunch grapes in North Carolina. NC Agric. Res. Serv. Bull. 470. 93 pp.

Smith, L.M., and E.M. Stafford. 1955. Grape pests in California. CA Agric. Exp. Sta. Circ. 445: 16-19.

Stafford, E.M., and F.L. Jensen. 1957. Grape leaffolder: field tests compared effectiveness of insecticides in control of vineyard pest. Calif. Agr. 11: $4,8,10,15$.

Strauss, J.F. 1916. The grape leaf-folder. USDA Bull. 419: 1-14. 